\title{
AGRONEGÓCIO E CAMPESINATO NA AMAZÔNIA BRASILEIRA: TRANSFORMAÇÕES GEOGRÁFICAS EM DUAS REGIÕES NOS ESTADOS DE RONDÔNIA E PARÁ*
}

\author{
Ricardo Gilson da Costa Silva** \\ Universidade Federal de Rondônia \\ Francilene Sales da Conceição ${ }^{* * *}$ \\ Universidade Federal do Oeste do Pará
}

Resumo: Na Amazônia brasileira o agronegócio da soja cristaliza os espaços da globalização, opondo o campesinato e as forças hegemônicas do capital. A produção familiar (campesinato) é pressionada pelos mecanismos coercitivos impostos pelas forças hegemônicas do capital, ancorado na modernização do espaço, através do agronegócio da soja. Este deve ser entendido como o processo multiescalar de conversão de áreas agrícolas em campo de expansão econômica do capital globalizado. Essa é a situação que atualmente se configura no sul do estado de Rondônia e no oeste do estado do Pará, notadamente nos municípios de Vilhena/RO, Santarém e Belterra/PA.

Palavras-chave: Geografia da Amazônia. Espaços da globalização. Campesinato. Agronegócio.

AGRIBUSINESS AND PEASANTRY IN THE BRAZILIAN AMAZON: GEOGRAPHIC TRANSFORMATIONS IN TWO REGIONS OF THE STATES OF RONDÔNIA AND PARÁ.

Abstract: Soy agribusiness in the Brazilian Amazon reflects the spaces of globalization. Through this dynamic peasantry opposes to the hegemonic forces of capital. Peasantry is pressed by coercive mechanisms imposed by this capital, embedded in the modernization of space. In this context agribusiness should be understood as a multiscale processes that leads the conversion of agricultural areas into others under the control of globalized capital. This is the situation currently being developed in the South of the Rondonia State and in the West of the State of Para, more precisely in the municipalities of Vilhena (RO), Santarém and Belterra (PA) .

Keywords: Amazon Geography, Globalization spaces, Peasantry, Agribusiness.

AGRONEGOCIO Y CAMPESINATO EN LA AMAZONÍA BRASILEÑA: TRANSFORMACIONES GEOGRÁFICAS EN DOS REGIONES EN LOS ESTADOS DE RONDÔNIA Y PARÁ

Resumen: En la Amazonia brasileña el agronegocio de la soja cristaliza los espacios de la globalización, oponiéndose al campesinado y las fuerzas hegemónicas del capital. La producción familiar (campesinado) es presionada por los mecanismos coercitivos impuestos por las fuerzas hegemónicas del capital, anclado en la modernización del espacio, a través del agronegocio de la soja. Este debe ser entendido como el proceso multiescalar de conversión de áreas agrícolas en campo de expansión económica del capital globalizado. Esta es la situación que actualmente se configura en el sur del estado de Rondônia y en el oeste del estado de Pará, notadamente en los municipios de Vilhena/RO, Santarém y Belterra/PA. Palabras clave: Geografía de la Amazonia. Espacios de la globalización. Campesinado. Agronegocios.

\footnotetext{
*O presente artigo compõe o projeto de pesquisa "Agricultura, território e espaços da globalização: aportes teóricos a partir da Argentina e Brasil", em desenvolvimento no Programa Postdoctoral en Ciencias Humanas y Sociales da Facultad de Filosofía y Letras de la Universidad de Buenos Aires, sob a supervisão da professora doutora Mariana Arzeno.

*Doutor em Geografia Humana, professor do Departamento de Geografia, do Programa de Pós-Graduação em Geografia e do Programa de Pós-Graduação Interdisciplinar Profissional em Direitos Humanos e Desenvolvimento da Justiça, coordenador do Grupo de Pesquisa em Gestão do Território e Geografia Agrária da Amazônia da Universidade Federal de Rondônia. Endereço: BR 364, Km 9,5, CEP: 76801-059, Porto Velho/RO. E-mail: rgilson@unir.br

${ }_{\star \star \star}^{*}$ Mestre em Geografia, professora substituta da Universidade Federal do Oeste do Pará, Av. Marechal Rondon, s/n, CEP 68040-070, Santarém/PA. E-mail: lenesalesgeo@ hotmail.com
} 


\section{Introdução}

Na Amazônia brasileira o agronegócio representa a cristalização dos espaços da globalização (SANTOS, 2005), cuja trama socioespacial opõe o campesinato e as forças hegemônicas do capital que transformam a agropecuária regional e, por conseguinte, o uso do território. Esse processo instaura um conjunto de transformações geográficas que (re)significam a região na divisão territorial do trabalho, manifestando "manhas" do meio técnico-científico-informacional que definitivamente impõe fragmentações no espaço regional, principalmente quando estes se abrem aos fluxos globais (SANTOS, 1996; SILVA, 2014b, 2015; BERNARDES, 2010).

O campesinato, que entendemos como classe social e modo de vida (OLIVEIRA, 1991), em seus respectivos territórios, é pressionado pelos mecanismos coercitivos impostos pelas forças hegemônicas do capital, ancorado na modernização regional através do agronegócio da soja. Tal situação geográfica deve ser entendida como um processo multiescalar, de conversão dos espaços agrícolas da produção familiar em campo de expansão econômica do capital globalizado, que adicionado à produção de commodities agrícolas se configura em espaços da globalização. Algumas regiões periféricas que apresentavam pouco dinamismo econômico, sob a ótica do capital, passaram a receber investimentos das grandes empresas globalizadas, transformando o espaço regional a partir de novas verticalidades (SANTOS, 1996), o que ampliou as relações local e global. Essa é a situação que atualmente se configura nos municípios de Vilhena (localizado no sul de Rondônia), Santarém e Belterra (localizados no oeste do Pará), ambos marcados pelo avanço da produção de soja (Figura 1), e objeto desta análise.

\section{FIGURA 1 - GEOGRAFIA DA PRODUÇÃO DE SOJA NA AMAZÔNIA (2013) LOCALIZAÇÃO DOS MUNICÍPIOS DE VILHENA (RO), BELTERRA E SANTARÉM (PA)}

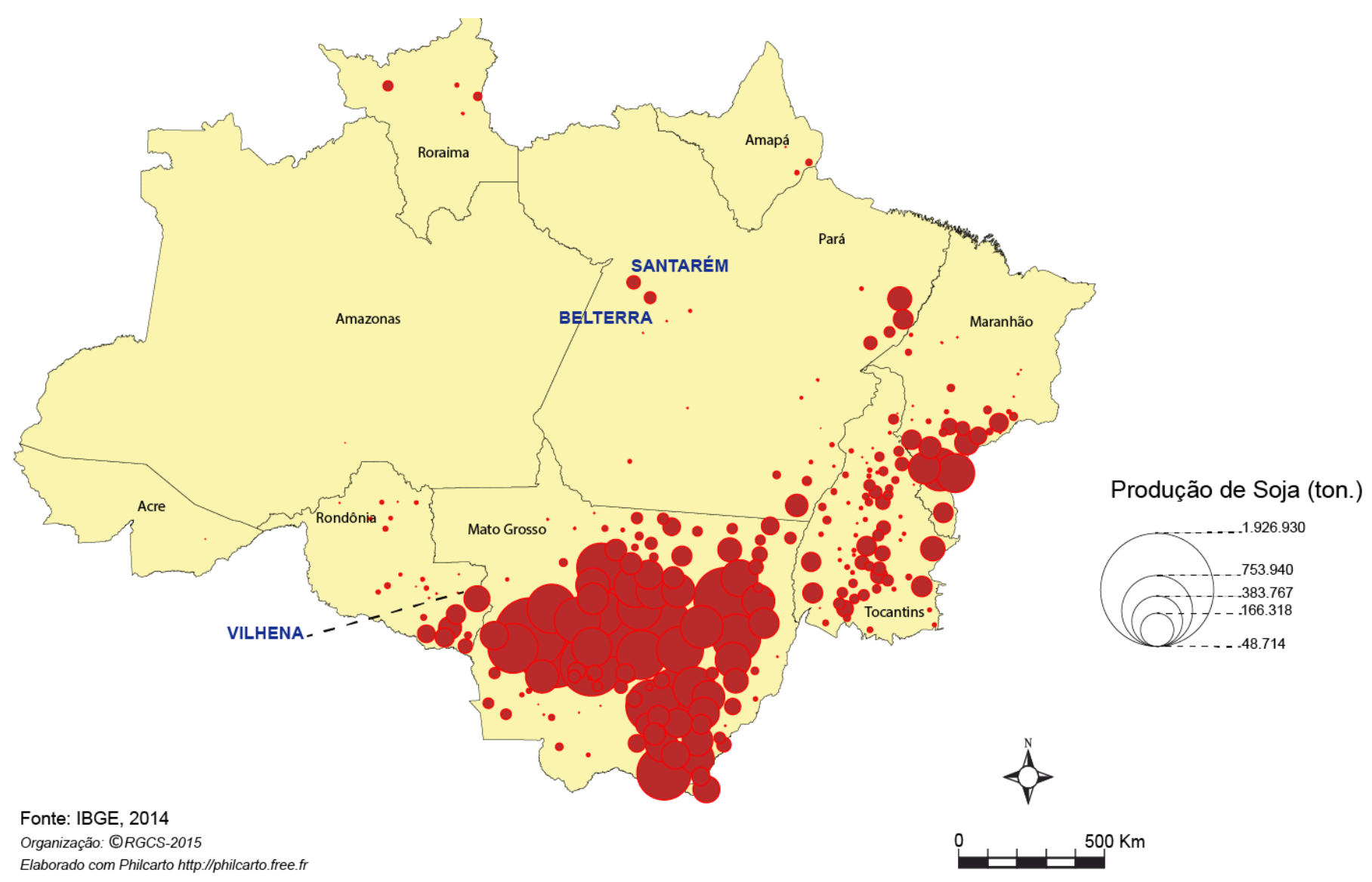

Em específico, a análise do agronegócio se torna relevante pelas transformações regionais que se instauraram nos lugares, considerando a formação socioespacial onde a presença do campesinato se cristalizou em função do processo de colonização agrícola. Nos municípios objeto deste texto, a soja comparece como elemento de reestruturação produtiva no espaço regional, criando verticalidades pelo capital global. A presença de grandes empresas, como Cargill, Amaggi, Bunge, entre outras, criam solidariedades 
organizacionais do capital (SANTOS; SILVEIRA, 2005), fragmentando o espaço regional em áreas de modernização da agricultura que se globaliza e, concomitantemente, expropria o campesinato.

Constatam-se transformações no espaço agrário estimuladas pelo capital globalizado, instaurando crises no uso do território, quando o espaço do campesinato diminui e o espaço do agronegócio avança. 0 entendimento do movimento do capital se realizando no ambiente local/regional a partir da produção de mercadorias e de domínio do território nos indica os arranjos espaciais emergentes que atravessam as regiões, sendo, pois, comandados de diferentes lugares, cujas hierarquias políticas, técnicas e informacionais se manifestam conflitivamente no espaço da produção.

Nesse sentido, o texto analisa essas dinâmicas territoriais a partir das contradições que opõem o campesinato e as comunidades tradicionais amazônicas frente ao capital do agronegócio em sub-regiões amazônicas, demonstrando as fragmentações produzidas pelo processo de globalização que atinge o espaço regional (Figura 1). Os camponeses e as comunidades tradicionais amazônicas, conceito expresso no universo da relação social entre homem/comunidades, natureza e território, categorizadas como ribeirinhos, pescadores, seringueiros, quilombolas, povos indígenas, dentre outros, esboçam em suas lutas e vivências os tensionamentos elaborados no processo de produção do espaço como totalidade histórica (SANTOS, 1998, 1996 e 2005), cujos desdobramentos concretos delineiam a formação dos territórios camponeses/comunidades frente ao território do agronegócio. Cristaliza-se a relevância da análise por verificar as mudanças na agricultura camponesa local em área de commodity, em que as monoculturas do agronegócio tendem a expulsar, pelo processo de expropriação e de coerção territorial do capital, as populações camponesas e as comunidades tradicionais amazônicas, representando uma nova fase de modernização conservadora no espaço agrário amazônico (PORTO-GONÇALVES, 2001).

\section{Geografia do agronegócio sojeiro em Rondônia}

As atuais metamorfoses territoriais no estado de Rondônia derivam do processo de colonização agrícola iniciado a partir de 1970, sob a gestão do Estado brasileiro, através do Instituto Nacional de Colonização e Reforma Agrária (INCRA), no qual foi sendo produzido um espaço substantivado pelas relações sociais de produção ancorada na extração madeireira e, principalmente, na agropecuária (THÉRY, 1976, 2012; VALVERDE, 1979; SILVA, 2012).

Esse período inaugura na Amazônia um novo meio geográfico - o meio técnico - onde, em larga escala, a floresta foi continuamente substituída pela expansão da agropecuária, designando na região a produção de mercadorias resultado das modificações econômicas na divisão territorial do trabalho, cujo espaço agrário modificado potencializa a transformação do espaço regional.

Na geografia de Rondônia, antes da colonização agrícola, o capital e o trabalho se realizavam através do extrativismo vegetal, potencializado na extração da castanha do Brasil, pescado, borracha, frutas e caça. Nesse período, o extrativismo mineral (extração da cassiterita) já havia penetrado a floresta, sobretudo na região do município de Porto Velho, mas, todavia, sem impor mudanÇas significativas na geografia regional (THÉRY, 1976, 2012). Isso significa que os capitais comercial e extrativista não criaram e não materializaram objetos técnicos que pudessem ampliar a composição técnica do espaço local, ou seja, as formas-conteúdo geográficas que ensejassem dinâmicas sociais e econômicas favoráveis à expansão/reprodução do capital. A configuração geográfica se restringia ao modelo ferroviário-fluvial, e somente a partir da colonização agrícola o campesinato migrante desenvolve a agropecuária, expandindo o processo produtivo através de dezenas de assentamentos rurais, médias e grandes fazendas, tornando o espaço local (meio técnico) mais poroso às dinâmicas regional e nacional (SILVA, 2015).

Esse processo avança até 1997, quando a geografia da Amazônia é permeada pela produção de novas mercadorias que representará, nos anos subsequentes, a cristalização do que Santos (2005) qualificou de espaços da globalização. A empiricização do mundo globalizado se manifestou em Rondônia a partir da produção de soja, que pressionada pela densidade dessa commodity no estado do Mato Grosso, ensejou a expansão agrícola para as bordas da floresta amazônica, localizada no sul de Rondônia e no oeste do Pará (conforme Figura 1). No caso de Rondônia, a inauguração de um novo sistema de objeto - a Hidrovia Madeira-Amazonas - sinalizou aos agentes econômicos do agronegócio (produtores de soja, empresas de insumos e tradings agrícolas) a possibilidade de reprodução do capital, inclusive em áreas de forte presença camponesa, a partir da aquisição e do arrendamento de terras, fazendo um uso corporativo do território (SANTOS; SILVEIRA, 2005; SILVA, 2015, 2014a, 2014b).

A geografia do agronegócio da soja se consolidou no sul rondoniense, centralizada pelo município de Vilhena, o maior produtor de soja e milho do estado (Figura 2). Vilhena se caracteriza por ser uma cidade do agronegócio e configura o que Elias (2012) qualificou de região produtiva agrícola, na medida em que reúne as articulações do espaço agrário e espaço urbano como híbridos 
dos processos mercantis da produção de soja, sendo um espaço cada vez mais aberto aos comandos e fluxos externos, onde a solidariedade organizacional (SANTOS; SILVEIRA, 2005) - conceito entendido como o processo de controle espacial do capital hegemônico a partir das determinações técnica e normativa da mercadoria, em que os produtores ficam obrigados a se vincular às redes que adicionam valor ao espaço produtivo - assume os mecanismos do capital hegemônico a partir da formação dos circuitos espaciais da produção e seus respectivos círculos de cooperação (SANTOS, 1988).

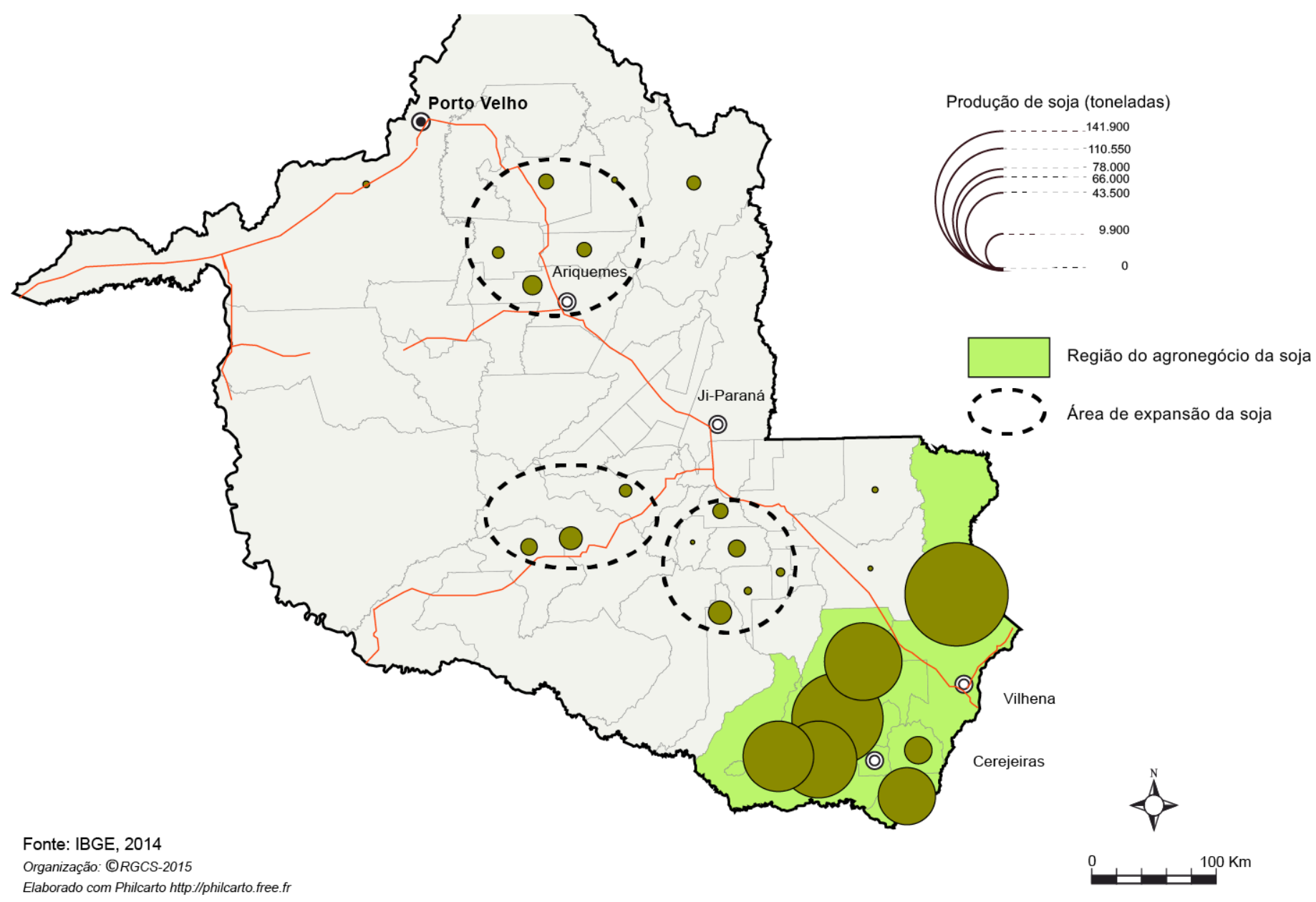

Com a Hidrovia do Madeira, a expansão da soja (Figura 3) cresceu das míseras 1.296 toneladas e 656 hectares em 1997 para 614.678 toneladas e 195.180 hectares em 2014, multiplicando em 474 vezes a produção e 298 vezes a área. Considerando que o município de Vilhena se caracterizava por apresentar grandes propriedades com produção de pecuária bovina de corte, instaura em Rondônia a primeira particularidade regional vinculada ao mercado externo: a regionalização da soja e a espe- cialização territorial da pecuária permite a fragmentação do espaço regional (SILVA, 2014a, 2014b). Qualifica-se essa dinâmica territorial quando se verifica que na composição da estrutura fundiária de Vilhena a diferença média de área entre a agricultura não familiar (normalmente agricultura capitalista) e a agricultura familiar é de 20 vezes, superando em 100\% a média estadual (10 vezes), conforme dados do Censo Agropecuário (IBGE, 2006). 


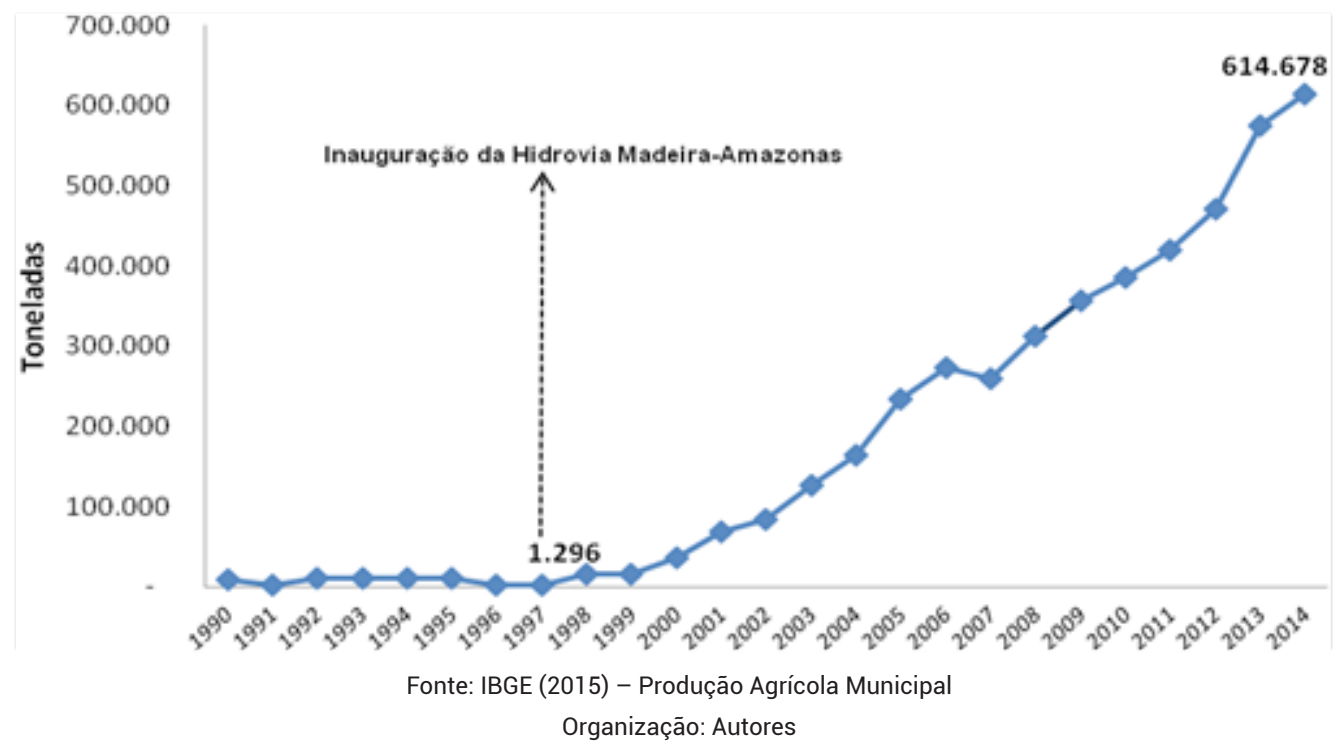

Alguns dados econômicos e sociais qualificam esse processo no município de Vilhena: apresentou $95 \%$ de taxa de urbanização (a maior de Rondônia); representou $35,31 \%$ das exportações (carnes e soja) de Rondônia em 2014 ( $1^{\circ}$ lugar); produziu 23\% dos grãos de soja, milho e arroz (2013) e centralizou a produção dos demais municípios, com a presença do capital hegemônico (JBS, Bunge, Cargill e Amaggi). A centralidade de Vilhena impõe a formação da região do agronegócio da soja (conforme figura 2), formada por sete municípios, que no conjunto representam $79 \%$ da produção de grãos (arroz $32 \%$, milho $79 \%$ e soja $89 \%$ ) em Rondônia (IBGE, 2015).

Resultam desse processo dois efeitos geográficos na região do agronegócio. Primeiro, os municípios com forte presença do campesinato sofreram processo de migração campo-cidade e campo-campo. Na primeira situação, a população rural, em geral formada por famílias camponesas, migrou para as cidades, o que se pode constatar no aumento da taxa de crescimento urbano em Rondônia e na região do agronegócio. No período intercensitário (2000-2010) a população estadual cresceu $13 \%$, a urbana $29 \%$ e a rural decresceu em $-16 \%$. Na região do agronegócio esses dados representam, respectivamente, $15 \%, 25 \%$ e $-15 \%$, sendo seu maior impacto nos pequenos municípios caracterizados pela maior presença de famílias camponesas. Dos sete municípios que formam a região do agronegócio, em cinco a população rural decresceu no período censitário, cujas taxas negativas variaram de $-9 \%$ a $-33 \%$ (IBGE, 2010).

Certamente esses dados também resultam do aumento do preço da terra derivado da pressão do agronegócio, que se traduz no processo de coerção territorial. Nos municípios em que a população rural aumentou, isso se deve à luta dos movimentos sociais que obrigou o governo federal a criar novos assentamentos rurais, em que muitos destes são resultado dos conflitos agrários com fazendeiros e sojicultores. Na segunda situação, o fenômeno da migração intraestadual se acentuou, sobretudo, nas sub-regiões de fronteira e de recente expansão agropecuária, formada por pequenos municípios onde se localizam áreas públicas que se tornaram objeto de ocupação irregular, grilagem e invasão de terras públicas, com pressão socioterritorial em Unidades de Conservação e Terras Indígenas (SILVA, 2016b).

A modernização conservadora da agricultura conduzida pelos agentes hegemônicos do agronegócio ampliou os conflitos agrários em Rondônia. Segundo os dados do Relatório Anual dos Conflitos no Campo 2014 organizado pela Comissão Pastoral da Terra (CPT), Vilhena foi o município do sul de Rondônia que mais apresentou conflitos agrários. Foram registrados conflitos envolvendo 206 famílias de sem-terra, 445 famílias de posseiros, 75 famílias de ocupantes e 224 famílias de assentados, somando um total de 950 famílias camponesas envolvidas, tendo como causa principal as forças do agronegócio da soja (CPT, 2014, 2016).

Ressaltamos que Rondônia apresentou um total de 2.977 famílias camponesas envolvidas em conflitos, e o município de Vilhena concentrou $31,9 \%$ deste número. Os fatores que acentuaram os conflitos agrários decorrem da saturação das áreas de plantio de grãos, o que fez aumentar a pressão para a incorporação de terras camponesas ao processo produtivo do agronegócio (RIBEIRO; SILVA; CORREA, 2015). Na região, o campesinato vivencia dias de grande pressão socioterritorial, na medida em que o agronegócio se coloca como modelo produtivo único centralizado nas médias e grandes propriedades, cuja agenda territorial e política busca obliterar e mesmo anular a produção e a presença social do campesinato. Contudo, as resistências camponesas emergem nas lu- 
tas pela terra, que se traduzem em novos assentamentos rurais na região do agronegócio, indicando novas territorializações do campesinato.

O Assentamento Águas Claras, localizado no município de Vilhena, é o que mais sofre as pressões do agronegócio, sobretudo em função da dimensão ambiental e territorial. Cercado pelo território do agronegócio, as propriedades camponesas (Figura 4) são impactadas pelos agrotóxicos lançados dos aviões que pulverizam as monoculturas de soja e milho, debilitando a saúde das famílias do assentamento e impactando seus produtos agrícolas. 0 crime ambiental foi objeto de denúncia dos assentados junto ao Poder Judiciário local, mas que não resultou em medidas eficientes e satisfatórias para os camponeses. A pressão territorial, para além da questão ambiental, avança a partir do litígio das terras ocupadas pelo campesinato. Dessa forma, a constante insegurança que assola o cotidiano das famílias no assentamento se deve às ameaças de morte e intimidação política que, segundo as lideranças, são oriundas dos fazendeiros da soja (RIBEIRO; SILVA; CORREA, 2015, p. 16-17).

\section{FIGURA 4 - TRABALHO CAMPONÊS NO ASSENTAMENTO ÁGUAS CLARAS, MUNICÍPIO DE VILHENA (2015)}

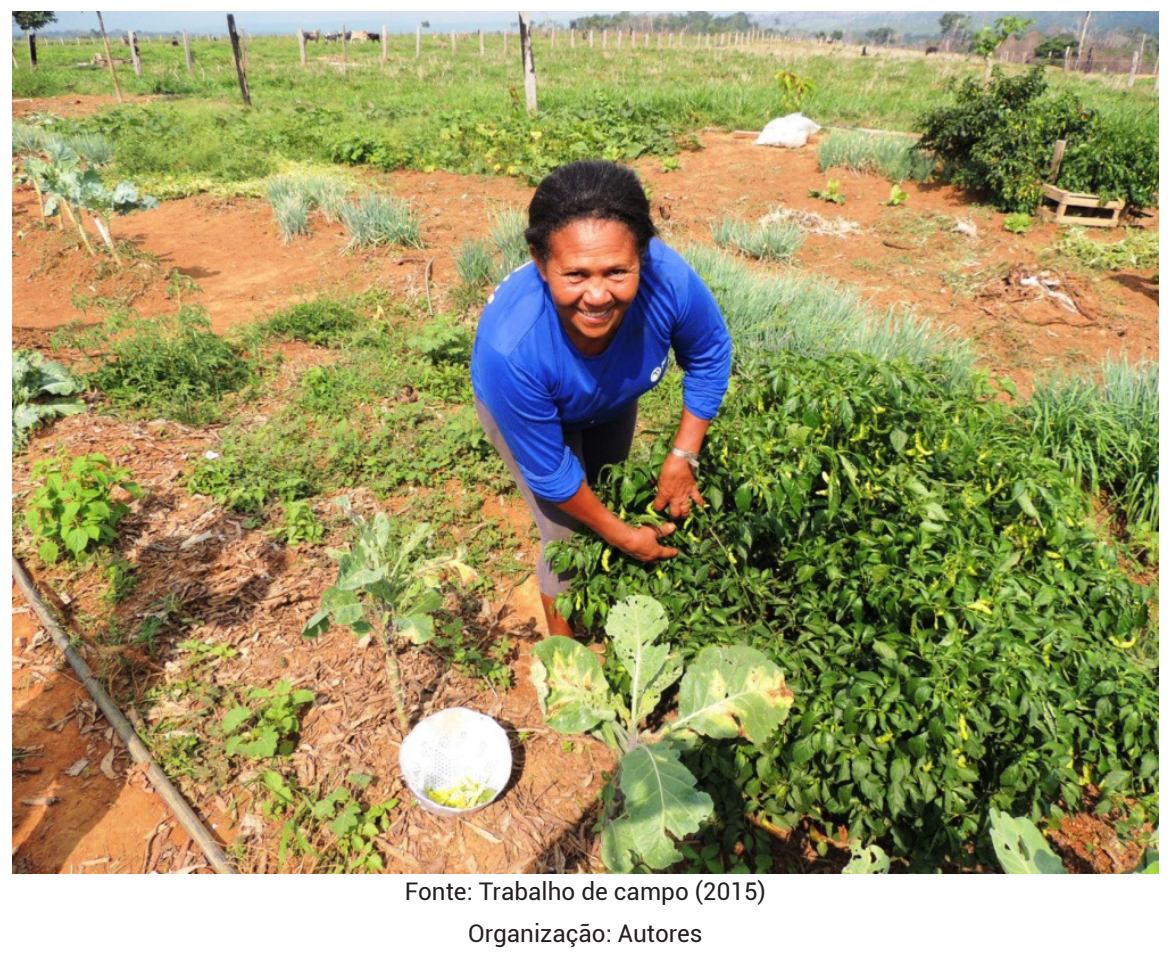

Os camponeses encontram-se intimidados pelos sojicultores, temem revidar contra aqueles que detêm o poder econômico-político e sofrer possíveis represálias desse modelo territorial excludente e contraditório, por isso acabam sofrendo pressões de todos os lados (instituições públicas, pistoleiros/jagunços, fazendeiros, Poder Judiciário). Sem alternativas de combater essa problemática avassaladora do agronegócio, sofrem impactos diretos nas suas pequenas propriedades, ora ambiental, ora social. Os produtores de soja, ao passarem o dessecante e/ou outros fertilizantes (agrotóxicos) nocivos à saúde humana, às plantas e outros vegetais nativos, com a ação dos ventos, deslocam para o interior das propriedades camponesas elementos tóxicos que destroem e eliminam as variedades de cultivos agrícolas, cuja finalidade é a manutenção da subsistência familiar e a comercialização de produtos no comércio local.

As coerções territoriais se agravam nesse cenário, que de um lado tem o território do agronegócio tentando ampliar suas áreas de influência e manter seu sistema hegemônico dominador, e do outro tem o território do campesinato que busca a todo custo resistir contra as forças do capital globalizado e continuar desenvolvendo a policultura a sua maneira por meio do trabalho familiar. Diante dessas emblemáticas disputas territoriais, destaca-se que a concentração fundiária é cada vez mais frequente no território do agronegócio, estimulando a supervalorização do preço das terras destinadas à produção de commodities.

A expansão agrícola fez com que o preço das terras na Amazônia aumentasse, ampliando os conflitos agrá- 
rios nas áreas ocupadas pelos camponeses. Diversas áreas foram reivindicadas pelos fazendeiros, cujas propriedades se ancoram em títulos públicos "duvidosos" ou pelas famosas CATPs' (Contrato de Alienação de Terra Pública) - que são questionadas pelo campesinato e pelo INCRA/Programa Terra Legal. Contudo, o campo de disputa política se deslocou para o Judiciário, ambiente institucional favorável ao latifúndio e prejudicial às pautas camponesas.

Nesse cenário, o campesinato em Vilhena e no sul de Rondônia experimenta as pressões da reestruturação produtiva no campo, as pressões políticas e territoriais das forças do agronegócio, que se colocam ideologicamente como modelo e caminho único de crescimento econômico e desenvolvimento social.

\section{Geografia do agronegócio sojeiro no oeste do Pará}

Formado, principalmente, pelos rios Amazonas, Trombetas e Tapajós, o oeste do estado do Pará se caracteriza por ser uma sub-região onde tempo-espaço é configurado pela presença dos rios na vida comunitária, pela exuberante massa florestal e rica vida silvestre, interligando centenas de comunidades ribeirinhas, que se formaram ao longo das margens dos rios e igarapés, às cidades locais.

Cidades ribeirinhas (TRINDADE JR.; SILVA; AMARAL, 2008) constitui a categoria de análise que melhor expressa a organização espacial nessa região da Amazônia brasileira, também denominada de Baixo Amazonas. A principal cidade é Santarém, localizada no encontro do rio Tapajós com o Amazonas, que exerce centralidade administrativa, econômica, política e cultural na região do Baixo Amazonas. Localizada nas margens do rio Trombetas, outra cidade importante é Oriximiná, conhecida pela extração de bauxita em áreas que outrora eram das comunidades quilombolas. 0 acesso a Oriximiná, a partir de Santarém, só pode ser feito através dos rios Amazonas e Trombetas, cujo percurso demora cerca de 9 horas em barco de transporte comercial. Projetos minerais e hidrelétricos e a resistência quilombola compõem a geografia dialética na região do Trombetas. Mais próxima de Santarém (50 km de distância) está a cidade de Belterra, localizada em região de planalto, às margens da rodovia BR-163 (Cuiabá-Santarém).

Outrora, as famílias que viviam nas comunidades do planalto santareno (que abrange áreas dos municípios de Santarém e Belterra) tinham sua cultura baseada na agricultura, no extrativismo sustentável e na caça como

TTítulo precário, emitido na década de 1980, com a finalidade de incentivar o povoamento e a produção agropecuária da Região Norte. Caracteriza-se por um contrato firmado pelo Incra, que autoriza a ocupação regular. Tem validade mediante o cumprimento das cláusulas resolutivas tais como: prever a obrigação de ocupar a terra, dar a função social ao imóvel, além da proibição de venda a terceiros. Assim, não cumpridos quaisquer desses compromissos, o contrato seria desfeito e o Incra poderia retomar a área (RIBEIRO; SILVA; CORREA, 2015). forma de garantir a subsistência familiar. No trabalho utilizavam técnicas artesanais, trocavam dias de serviços nas propriedades dos vizinhos, compartilhavam alimentos e outros produtos agrícolas, faziam mutirões e programavam as festividades religiosas dos santos padroeiros das comunidades. De certo modo, obedeciam ao tempo da natureza para derrubar, plantar, produzir e colher, pois através do trabalho coletivo faziam seus roçados e plantavam variados produtos agrícolas (arroz, feijão, milho, mandioca, macaxeira) e outros agrocultivares como legumes, hortaliças e frutas, além da criação de animais (CONCEIÇÃO, 2017).

A safra obtida da agricultura era anual, porque dependia do ritmo do "inverno" amazônico, caracterizado por regime de intensa pluviosidade. Aguardar o período das chuvas para "molhar" a terra e, consequentemente, as plantações se tornava necessário para que os camponeses obtivessem uma produção agrícola significativa. As mercadorias agrícolas, além de servir ao consumo familiar, destinavam-se ao abastecimento dos mercados local e regional. Utilizavam o sistema corte-queima, a policultura e a rotação de culturas. Esse sistema se baseava no uso da terra e da floresta, caracterizando uma nova tipologia de campesinato, com um perfil agroextrativista.

As práticas das policulturas garantiam renda e a manutenção da soberania alimentar ${ }^{2}$ das famílias camponesas (Figura 5). Além de realizar a agricultura, a extração de produtos da floresta também constituía um fator predominante. Coletavam sementes e frutos de andiroba, castanha-do-pará, cumaru, pequiá, oxí, maracujá-do-mato, jenipapo, pajurá, mucajá ou macaúba, tucumã, abacaba etc., e extraíam óleo de copaíba e leite da sucuba, produtos da floresta que ajudavam na qualidade de vida e de grande aceitação no comércio local, permitindo-Ihes auferir renda monetária derivada do extrativismo. Mesmo com grande variabilidade de espécies, as famílias camponesas plantavam seus remédios medicinais nos quintais de suas casas, a fim de combater as doenças na família ou na vizinhança, caracterizando um regime baseado em relações de proximidade e de saberes tradicionais (CONCEIÇÃO, 2017).

${ }^{2}$ Este é um conceito utilizado pelas populações camponesas para se referirem a seu respectivo modo de vida: tem a ver com uma produção autônoma, diversificada (cultivo de vários produtos agrícolas), saudável, que garante a subsistência da família e de toda a comunidade, além de exercer o direito do campesinato em respeitar o meio ambiente, devendo os mesmos manterem a preservação e a conservação dos recursos naturais. Contrasta, portanto, com o conceito de segurança alimentar, entendido simplificadamente como a capacidade de adquirir alimentos - uma perspectiva econômica neoclássica - sem necessariamente preocupar-se com a forma e o local onde é produzido o alimento. A soberania alimentar é mais ampla e se relaciona com a vida humana, almejando um ambiente ecologicamente equilibrado e socialmente justo e sustentável (MCMICHEL, 2016) 


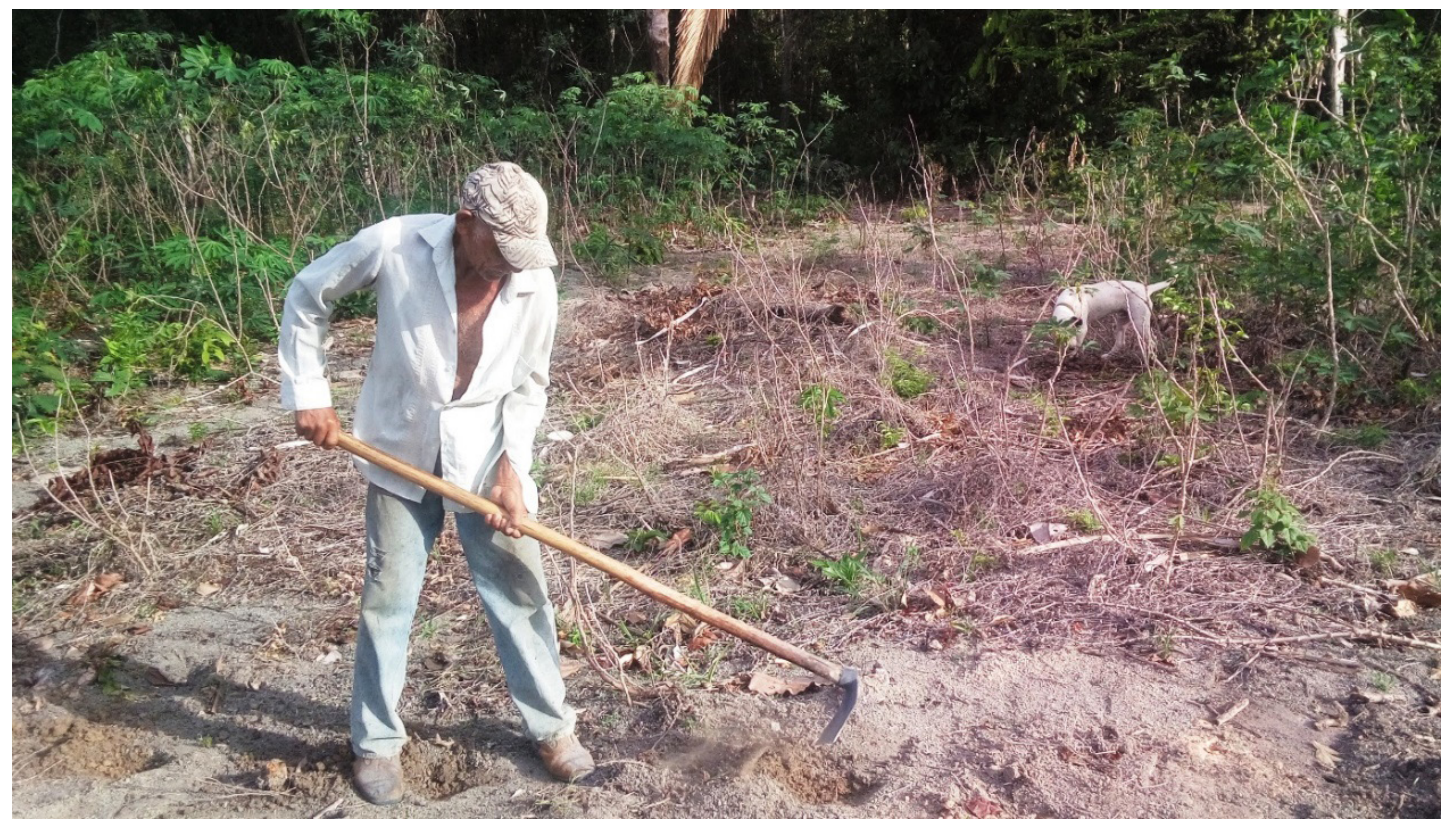

Fonte: Trabalho de Campo (2016)

Foto: F. S. C.

Quando a maioria das comunidades rurais não tinha energia elétrica, utilizavam lamparina, lampião ou velas para não permanecer no escuro. Como técnica de conservação dos alimentos (principalmente carnes e peixes), salgavam ou secavam ao sol, definindo a durabilidade máxima para serem consumidos em duas semanas. A água ingerida era natural e os depósitos de armazenamento da água eram os potes ou os filtros. Para o campesinato a natureza condicionava suas ações e seu trabalho, determinando a produção dos alimentos (OLIVEIRA, 1991). Os camponeses somente se deslocavam à cidade esporadicamente, porque tinha quase tudo de que necessitavam para seu consumo nas propriedades onde viviam. Da cidade precisavam comprar alguns gêneros alimentícios, ferramentas de trabalho ou comercializavam seus produtos agrícolas nas feiras dos municípios de Santarém e Belterra.

Algumas comunidades enfrentavam o problema da água na região de planalto, onde o nível do lençol freático é profundo e as condições financeiras das famílias camponesas não lhes permitiam construir poços artesianos. Portanto, a escassez hídrica obrigava as famílias a fazerem uso de alguns reservatórios que surgiam espontaneamente (pequenas "poças"), coletando águas das chuvas, utilizando "bicas" 3 para depositar água em cisternas ou tanques. A problemática enfrentada por essas famílias decorre das ineficientes políticas públicas, que ainda são perceptíveis em algumas comunidades rurais. Atualmente, em Belterra, as famílias residentes no pla-

3É uma calha onde a áqua proveniente do processo de precipitação cai sobre esse objeto e percorre até completar todo seu o trajeto, local que será depositado o líquido em um recipiente. Na Amazônia é muito comum as famílias utilizarem nas suas residências, podendo ser feito de troncos de árvores ou de canos. nalto são atendidas por um "carro-pipa", sendo a "alternativa" adotada pela Prefeitura Municipal para atender a população com o abastecimento d'água. Assim, mesmo localizados na maior bacia hidrográfica do mundo, há comunidades com dificuldades de acesso à água, o que contribui indiretamente com a migração da população rural para a cidade. Em período recente, a divisão social do trabalho caracterizava-se na figura do pai - representado como o "chefe da família" -, da mãe e dos filhos e outros parentes. Juntos, formavam a unidade familiar do campesinato baseada na indissociabilidade terra, natureza, família e trabalho.

Todavia, no espaço agrário a economia globalizada se pauta pela produção de commodities, buscando disputar áreas consolidadas, sobretudo, pelo campesinato. Segundo Schlesinger e Noronha (2006), no Pará, o cultivo dos grãos de soja e a incorporação do agronegócio ao mercado agroexportador alavancou a partir do ano de 1997, destacando os municípios de Paragominas e Ulianópolis, no nordeste paraense, e em 1998 essa cultura agrícola se expande para os municípios de Redenção e Conceição do Araguaia, no sul do estado. Nesse período a soja começou a ser inserida nos municípios de Santarém e Belterra, oeste do Pará. A ressignificação da rodovia BR-163 em 1997, como eixo de transporte emergente da soja, abriu a região do Baixo Amazonas ao fluxo da globalização, ampliando os grãos de soja em áreas então sob domínio campesino e das comunidades tradicionais amazônicas.

Tanto para Rondônia quanto para a região do Baixo Amazonas, o ano de 1997 indica a virada espacial do agronegócio em áreas com forte presença campone- 


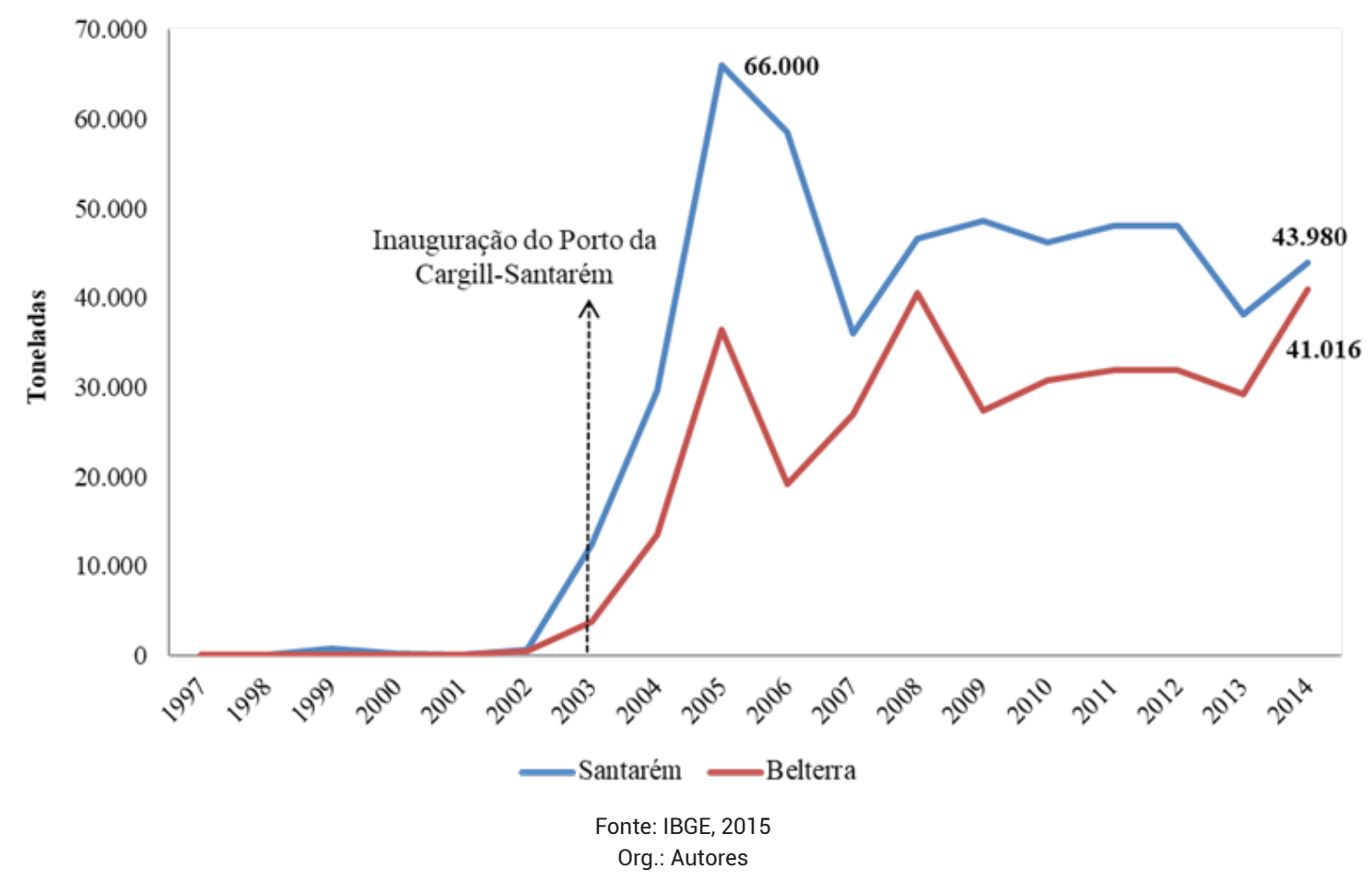

sa. Em Santarém a produção iniciou com 107 toneladas, atingindo 66.000 toneladas em 2005, e reduzindo a 43.980 toneladas em 2014. Para Belterra, o início demorou mais um pouco, aparecendo a primeira colheita em 2002, com produção de 450 toneladas de soja. A fase experimental se mostrou muito positiva aos sojeiros, que ampliaram significativamente a produção agrícola, saltando de 3.780 toneladas em 2003 para 13.500 toneladas em 2004, 36.450 toneladas em 2005 e 40.500 toneladas em 2008, mantendo aproximadamente esses números nos dias atuais (Figura 6). As culturas de arroz e milho foram utilizadas para "amansar" a terra, que serviram, posteriormente, ao plantio da soja. Em Belterra a produção de soja aumentou espantosamente, atingindo áreas urbanas, tornando-se uma particularidade emergente na paisagem da cidade.

Toda essa geografia emergente é resultado da construção estratégica do terminal graneleiro da Cargill, localizado às margens do rio Tapajós, em Santarém (Figura 7). A partir do ano 2000 se intensificou a movimentação de cargas e transportes na rodovia BR-163 (Cuiabá-Santarém) e contribuiu com o aumento dos grãos nos municípios de Santarém, Belterra e Mojuí dos Campos, que estão sob a influência dessa rodovia. Tanto o porto da Cargill como a pavimentação da rodovia constituem sistemas de engenharias ${ }^{4}$ (SANTOS, 1998, 1996 e 2005) de tamanha complexidade que modificaram, sobremaneira, a geografia local, dado que os novos objetos téc- nicos surgiram na paisagem ribeirinha de Santarém e da agricultura camponesa de Belterra, construindo um novo significado ao lugar, mas também tornando-se objetos estranhos à história local. Isso ampliou a escala geográfica da relação social, dos espaços rural e urbano, onde os fluxos das commodities articularam o local com o global, aproximando o mundo ao lugar e ao território.

A instalação do capital mostra que o agronegócio exige cada vez maiores investimentos em seus projetos hegemônicos. A presença desse sistema de objeto (terminal portuário) na foz do Tapajós modificou os aspectos estrutural e funcional do espaço regional. Nesse contexto, o capital hegemônico transformou o espaço local em um sistema agroexportador bem expressivo no cenário regional, cujo objetivo é acelerar a fluidez territorial (ARROYO, 2001) na Amazônia, garantindo o fluxo da mercadoria em escala internacional. 


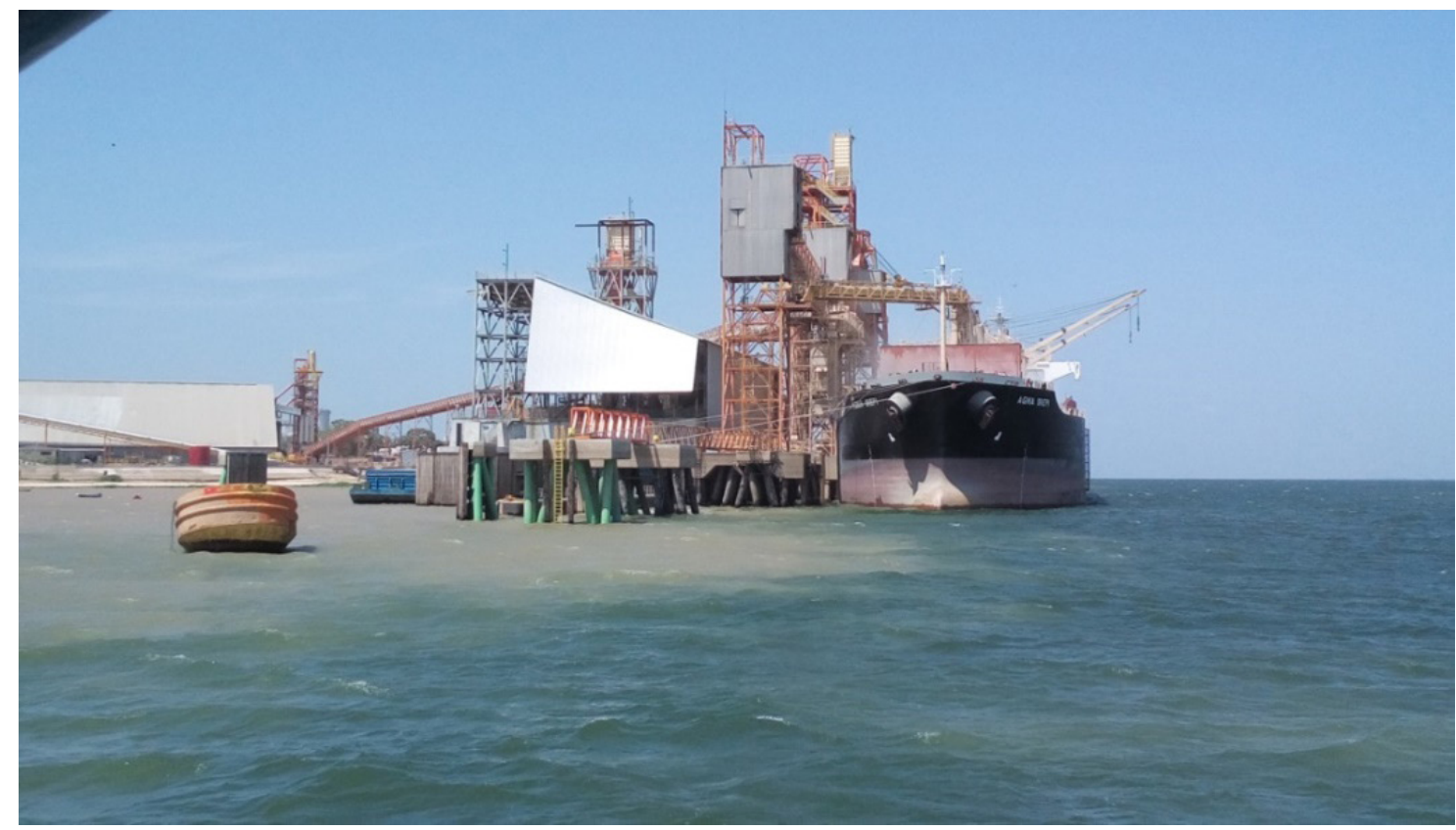

Fonte: Trabalho de Campo (2016)

Foto: F. S. C.

As forças hegemônicas do agronegócio (Cargill, produtores de soja, empresas de insumos e de transportes, dentre outras) vislumbraram a rodovia Cuiabá-Santarém como novo corredor do agronegócio, conectando o cerrado mato-grossense à floresta amazônica, cuja metamorfose espacial foi transformar áreas de pastagens, áreas florestais e da agricultura camponesa em espaço das commodities, portanto, em um novo espaço de acumulação do capital globalizado.

A abertura concedida aos novos mercados globais nos espaços antes habitados pelo campesinato fez emergir novas relações dialéticas sobre o uso do território. Esse processo contraditório resultou na ampliação do "mercado de terras" e na elevação do preço do hectare, metamorfoseando o valor de uso para o valor de troca das terras (OLIVEIRA, 1991), a fim de atender as pretensões do mercado mundial. Desse modo, no período de 2002 a 2014, a soja invade o oeste do Pará (cidades de Santarém e Belterra), onde a produção cresce de 1.050 toneladas (2002) para 84.996 toneladas (2014), multiplicando por 80 a produção inicial (Figura 6). Tais dados, certamente, representam um volume insignificante em termos amazônicos, cuja produção foi de 31.661.247 milhões de toneladas em 2014, mas indica os caminhos do agronegócio em áreas com potenciais agrícolas, no qual a Amazônia comparece como nova fronteira agrícola globalizada, dada a "disponibilidade" de terras, sobretudo terras públicas em disputas pelas forças hegemônicas do agronegócio (SILVA, 2014a, 2015).

Contudo, os efeitos na geografia agrária são imediatos. Como afirmamos, esses dois municípios estão na região de influência da BR-163, que se constitui em área de expansão de grãos (soja, milho e arroz). 0 avanço das commodities inflacionou o preço da terra, tornando-se um campo de acumulação da especulação fundiária, processo que remunera o capital agrário e os proprietários de terras, considerando as expectativas de demanda por terras em função do crescimento da produção dos grãos. Conforme os dados da pesquisa Informa Economics FNP (2015), no período de 2010/2014, o preço da terra agrícola e da pastagem em Santarém e Belterra cresceu, respectivamente, $676 \%$ e $434 \%$ (ver adiante Tabela 2). Por isso, convergem os interesses dos grupos empresariais e políticos articulados ao agronegócio em pavimentar a rodovia Cuiabá-Santarém. Os investimentos assentados em redes de transportes e portos permitem a valorização das terras em áreas propícias à produção agrícola, potencializando a competitividade regional a partir da melhoria na fluidez do território (ARROYO, 2001).

A perspectiva de se implantar mais um porto de transbordo de granéis sólidos em Santarém, no lago do Maicá, margem direita do rio Amazonas, tende a ampliar as disputas por terras, a concentração fundiária e a desterritorialização do campesinato, indígenas, quilombolas e ribeirinhos (CONCEIÇÃO, 2017). O projeto previsto para a construção de um dos terminais se encontra em análise e está sob a responsabilidade da Empresa Brasileira de Portos de Santarém Ltda (EMBRAPS). A construção de outros terminais graneleiros na região significa criar logística para facilitar a fluidez territorial e permitir a manutenção de um mercado de terras superaquecido (LOPES, 2016).

Os reflexos da elevação dos preços das terras foram evidentes em muitas comunidades do planalto. Antes 


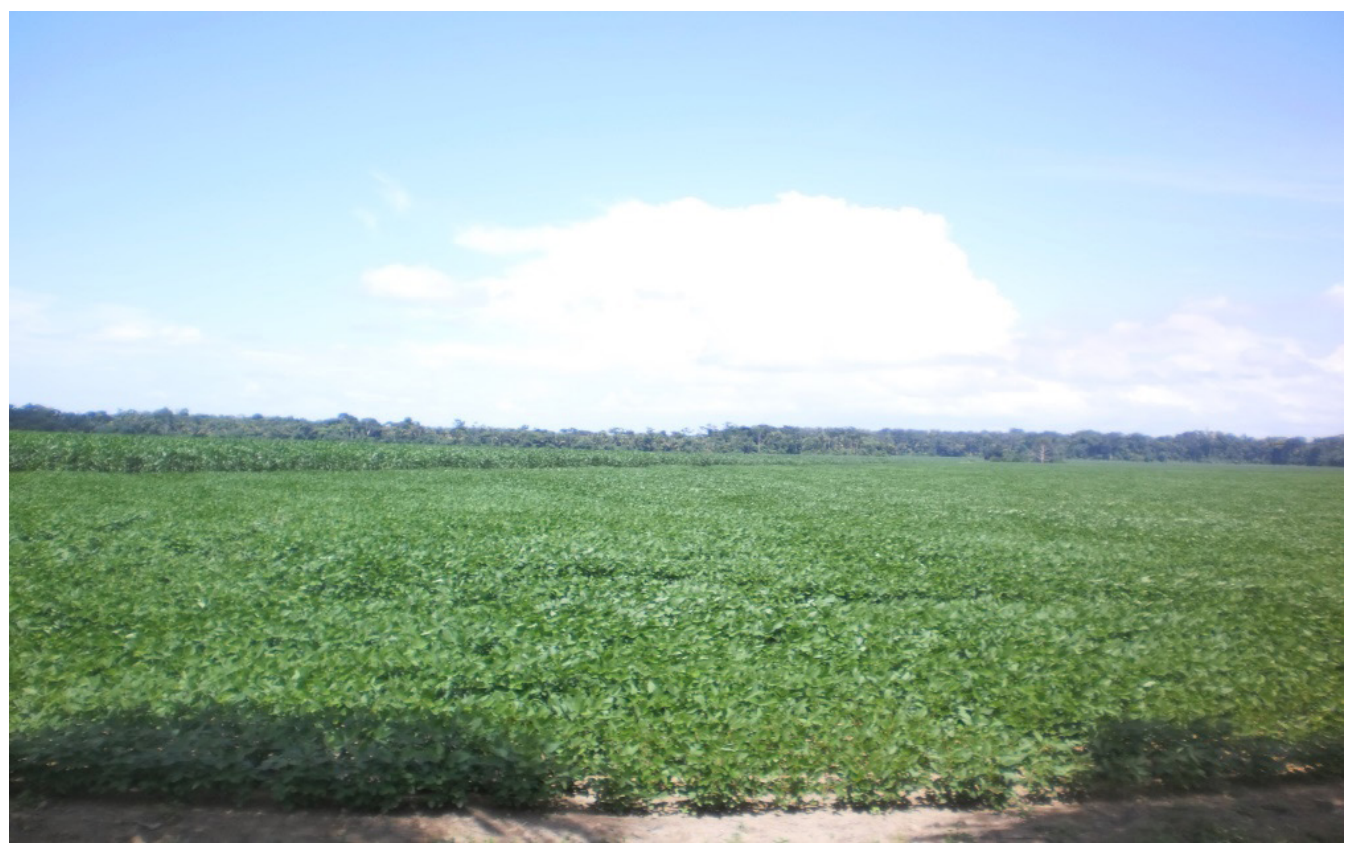

Fonte: Trabalho de Campo (2014)

Foto: F. S. C.

da chegada dos sojicultores sulistas em Santarém e Belterra, o hectare de terra não ultrapassava R\$ 200,00. Mais recentemente o preço da terra agrícola atingira $\mathrm{R} \$$ 7.000,00 (CONCEIÇÃO, 2017). A "disponibilidade" de terras, o preço acessível de terras e a logística de transportes (rodovia e hidrovia) encontrados no oeste do Pará despontaram como fatores para que migrantes sulistas adquirissem muitas áreas agrícolas e provocassem tantas mudanças no espaço agrário da região. 0 avanço do agronegócio sojeiro fez com que a sociabilidade monetária do capital permeasse a vida cotidiana das comunidades rurais. Um dos efeitos se manifestou na compra de terras camponesas a preço muito inferior ao do mercado, facilitando a formação de fazendas do agronegócio (Figura 8).

Mas as relações capitalistas também se desenvolvem usando da violência, da agressão simbólica e das representações sociais sobre a natureza e a terra, mobilizando-as como mercadorias. Os camponeses são atingidos pelos conflitos agrários. A terra, na perspectiva do campesinato, é uma condição fundamental para a recriação da classe social camponesa e que permite a manutenção da vida. 0 território do campesinato faz uso da policultura, busca sua autonomia no ato de produzir, possui uma diversidade em seus produtos agrícolas e tem a família como a base fundamental do trabalho (OLIVEIRA, 1991). É o que relata um camponês entrevistado na pesquisa de campo, no município de Belterra (1): "Ah, a terra pra mim representa uma mãe [...] é um patrimônio meu, porque é dela que sai toda a nossa alimentação" (CONCEIÇÃO, 2017).

0 campesinato não está isento de conflitos. Os cam- poneses estão constantemente sujeitos às ameaças de mortes, às grilagens de terras e sofrem constantemente pressões do agronegócio. No relato de um camponês entrevistado (2), cristalizam-se esses conflitos: "Aí pros fundo, aí é plantio de soja aí..., aí só que os de lá vêm entrando, de lá pra cá, devagazinho, né? Aí tem que fincar uns marcos lá, que é pro cabra não poder entrar mais pra dentro, trabalhar no que é deles, né?". Os camponeses querem o direito de desenvolver uma agricultura saudável, autônoma e que possa garantir uma vida justa para suas famílias, sem que necessariamente o outro modelo possa prejudicar o seu trabalho e aquilo que é produzido na terra. Trata-se de um direito ao território, a um outro território que possa expressar sua rica diversidade social.

Os venenos utilizados nas plantações de soja matam as plantações do campesinato. Algumas comunidades do planalto não conseguem nem mais produzir nas suas propriedades porque são prejudicados por esse tipo de atividade. Ainda, quando os camponeses adotam providências junto aos sojicultores, são imediatamente recebidos com ameaças de morte. Diante dos acontecimentos, as lutas socioterritoriais para permanecer na terra estão presentes na realidade dos municípios de Santarém e Belterra. Apesar das resistências, muitos camponeses se encontram temerosos, pensam em vender suas propriedades porque se sentem pressionados e coagidos pelo capital. Esses sujeitos almejam o direito de plantar, produzir e colher, mas, acima de tudo, querem o direito de viver com sua família no território campesino, de forma que esteja livre de pressões e intimidações do capital (CONCEIÇÃO, 2017). 
Síntese geográfica do agronegócio da soja no sul de Rondônia e oeste do Pará

A presença da soja no sul de Rondônia e no oeste do Pará permite-nos elaborar alguns apontamentos referentes à nova espacialidade que atinge diretamente os camponeses, as comunidades ribeirinhas, quilombolas, pescadores e outros modos de vida que coexistem na região amazônica. Consiste, em absoluto, na formação do espaço do agronegócio globalizado, o que resulta na formação do território do agronegócio em detrimento e em conflito com o território do campesinato e das comunidades rurais amazônicas, o que remete ao entendimento das escalas geográficas nas relações sociais e econômicas nas regiões em análise.

$\mathrm{Na}$ escala nacional e internacional há todo um esforço das agências públicas em ampliar a presença do Brasil no comércio global de commodities agrícolas, buscando sempre conquistar novos mercados. As projeções para o crescimento até a safra $2024 / 2025$ da produção e área de soja no Brasil são, respectivamente, de 126,2 milhões de toneladas e 41,2 milhões de hectares, com aumento de área na ordem de 9,7 milhões de hectares no período de 2014/2015 a 2024/2025 (BRASIL, 2015). A perspectiva é que o Brasil possa, a partir do desempenho da soja no período citado, ampliar a produção em $33,9 \%$, o consumo em $22,9 \%$ e a exportação em $42,21 \%$ (BRASIL, 2015 , p. 42). Para o mercado mundial, no mesmo período, as exportações de soja (69 milhões de toneladas e $45,9 \%$ do comércio externo) e farelo de soja (17,9 milhões de toneladas e $23,6 \%$ do comércio mundial) projetam o fortalecimento do Brasil no comércio exterior, assumindo papel fundamental na geopolítica agrícola mundial.

Ainda que se registre o aumento da produtividade dos fatores da produção do complexo soja (terra, capital, tecnologia e trabalho), a questão da expansão espacial dos grãos pode gerar uma nova geografia regional quando se observa o crescimento agrícola na região do MAPITOBA5(ALVES, 2015), configurando-se em nova fronteira agrícola globalizada, deslocando a pressão territorial da Amazônia para essa nova região produtiva. Contudo, embora sejam moderadas as avaliações governamentais para a Amazônia, o crescimento da produção e área agrícola com soja e milho na região indica intenso processo de territorialização do capital, ocupando áreas que outrora se destinavam à pecuária e à pequena produção agrícola. Essas perspectivas nos remetem a analisar os efeitos territoriais das macropolíticas agrícolas desenvolvidas pelo governo federal na região amazônica.

$\mathrm{Na}$ escala regional os espaços em disputas cada vez mais se cristalizam na Amazônia, onde as forças do agronegócio exercem pressão territorial a partir do Mato Grosso. As sub-regiões norte e médio norte mato-grossense formam o espaço do agronegócio sojeiro, caracterizado por uma logística limitada e custos de transportes altíssimos que tendem a fragilizar a competitividade do Mato Grosso no comércio global. Nesse caso, duas frentes de ações se consolidam nesse propósito: a pavimentação da rodovia BR-163 que liga Cuiabá (MT) a Santarém (PA) e a construção da hidrovia Teles Pires-Tapajós. Segundo estimativas, a produção das sub-regiões norte e médio norte, que reúnem 33 municípios, representa $40 \%$ da área plantada com soja, $18,3 \%$ da área com algodão, $50 \%$ da área com milho e $22,5 \%$ do rebanho bovino no estado do Mato Grosso (IBGE, 2015).

Portanto, a necessidade de fluidez territorial (ARROYO, 2001) alude à implantação de mais objetos técnicos que possam aproveitar os recursos territoriais disponíveis a tornar essas sub-regiões mato-grossense mais atrativas ao capital internacional. A pauta territorial das forças hegemônicas do agronegócio impõe a construção de redes técnicas, redes geográficas, para convergir o fluxo da mercadoria aos portos de Santarém, no oeste do Pará. Há uma potencialidade do agronegócio nessas regiões, cuja força de crescimento vincula-se inexoravelmente à melhoraria da logística e ao custo de transporte, ou seja, a produção do espaço regional articulado aos fluxos da globalização (SILVA, 2014b, 2015; CONCEIÇÃO, 2017). 
TABELA 1 - EVOLUÇÃO DO PREÇO MÉDIO DA TERRA NA AMAZÔNIA, 2010-2014 (R\$/HECTARE)

ESTADOS SELECIONADOS

\begin{tabular}{|c|c|c|c|c|c|c|c|c|c|}
\hline \multirow[t]{2}{*}{ Estado } & \multicolumn{2}{|c|}{ Rondônia } & \multicolumn{2}{|c|}{ Pará } & \multicolumn{2}{|c|}{ Mato Grosso } & \multicolumn{3}{|c|}{ Variaçāo (\%) } \\
\hline & 2010 & 2014 & 2010 & 2014 & 2010 & 2014 & RO & PA & MT \\
\hline $\begin{array}{l}\text { Preço médio } \\
\text { da terra }\end{array}$ & 2.733 & 5.677 & 2.635 & 6.236 & 744 & 1.458 & 108 & 137 & 96 \\
\hline
\end{tabular}

Fonte: FNP, 2015.

Organização: Autores.

TABELA 2 - EVOLUÇÃO DO PREÇO MÉDIO DA TERRA NA AMAZÔNIA, 2010-2014 (R\$̣/HECTARE) MUNICÍPIOS SELECIONADOS

\begin{tabular}{|c|c|c|c|c|c|c|c|c|c|}
\hline \multirow{3}{*}{$\begin{array}{l}\text { Terra } \\
\text { agrícola }\end{array}$} & \multicolumn{2}{|c|}{$\begin{array}{l}\text { Vilhena } \\
\text { (RO) }\end{array}$} & \multicolumn{2}{|c|}{$\begin{array}{l}\text { Ariquemes } \\
\text { (RO) }\end{array}$} & \multicolumn{2}{|c|}{$\begin{array}{r}\text { Santarém / } \\
\text { Belterra (PA) }\end{array}$} & \multirow[t]{2}{*}{ Vilhena } & \multirow[t]{2}{*}{ Ariquemes } & \multirow[t]{2}{*}{ Santarém/Belterra } \\
\hline & \multicolumn{6}{|c|}{ Preço médio $(\mathrm{R} \$ / \mathrm{Ha})$} & & & \\
\hline & 7.733 & 13.117 & 2.200 & 6.750 & 967 & 7.500 & 70 & 207 & 676 \\
\hline $\begin{array}{l}\text { Área de } \\
\text { pastagem }\end{array}$ & 2.400 & 8.167 & 2.200 & 6.300 & 867 & 4.633 & 240 & 186 & 434 \\
\hline
\end{tabular}

Fonte: FNP, 2015

Organização: Autores.

Os efeitos territoriais se fazem presentes nas regiões sul de Rondônia e oeste do Pará, sobretudo, incidindo no preço da terra (Tabelas 1 e 2). Conforme indicamos, nos municípios que centralizam a produção de grãos o preço da terra foi pressionado pela expectativa de construção de redes de transportes, sinalizando aos produtores de soja um verdadeiro comércio territorial com expressiva compra e arrendamento de áreas em regiões promissoras à expansão agrícola, considerando que a redução dos custos de transporte e logística amplia consideravelmente a competitividade regional.

\section{Rondônia: expansão agrícola e conflitos agrários}

Em Vilhena (sul de Rondônia), o comércio de terras está saturado devido às limitações geográficas em termos de áreas ainda "disponíveis", geralmente terras públicas ainda não destinadas à produção de grãos. A conversão das pastagens para a agricultura constituiu a dinâmica territorial predominante nessa região. Como resultado, conforme dados da Tabela 2, enquanto a variação da área agrícola foi de $70 \%$, as pastagens cresceram $240 \%$, indicando que a escassez de terras teve como resultado sua elevação na pecuária, sobretudo em áreas não favoráveis aos grãos ou de abertura recente. Esses efeitos econômicos encontraram terreno fértil nas áreas ao longo da rodovia BR-364, sobretudo na região de Ariquemes (novo polo agrícola e frente de desmatamento), cujo resultado, no período de 2010 a 2014, foi o aumento absoluto do mercado de terras, variando $207 \%$ para a terra agrícola e $186 \%$ para áreas de pastagens (Tabela 2). Em Rondônia, o preço médio geral da terra agrícola correspondeu a 108\% (Tabela 1), aumentando nas áreas de recente expansão agrícola e pecuária, exatamente as regiões com maior conflito agrário no estado (CPT, 2016). Ou seja, o preço da terra subiu no sentido da região da soja para as áreas de expansão agropecuária, exploração ilegal de madeira e formação de frentes pioneiras localizadas, no sentido cartográfico do centro-sul para o norte/noroeste de Rondônia (SILVA, 2016b). 


\begin{tabular}{|c|c|c|c|c|c|c|c|c|}
\hline \multirow[t]{2}{*}{ Municípios/Estado } & \multicolumn{5}{|c|}{ Populaçāo (2010) } & \multicolumn{3}{|c|}{ Variaçāo (2000-2010) } \\
\hline & Total & Urbana & Rural & Urb. (\%) & Rur. (\%) & Total & Urbana & Rural \\
\hline Vilhena & 76187 & 72212 & 3975 & 95 & 5 & 42 & 43 & 33 \\
\hline Colorado do Oeste & 18602 & 13666 & 4936 & 73 & 27 & -15 & -6 & -33 \\
\hline Cerejeiras & 17030 & 14420 & 2610 & 85 & 15 & -6 & -3 & -22 \\
\hline Corumbiara & 8802 & 2590 & 6212 & 29 & 71 & -16 & 25 & -26 \\
\hline Cabixi & 6309 & 2693 & 3616 & 43 & 57 & -16 & 1 & -25 \\
\hline Chupinguaia & 8304 & 3670 & 4634 & 44 & 56 & 50 & 88 & 30 \\
\hline Pimenteiras do Oeste & 2322 & 1297 & 1025 & 56 & 44 & -8 & -7 & -9 \\
\hline Regiāo Agronegócio & 137.556 & 110.548 & 27.008 & 80 & 20 & 15 & 25 & -15 \\
\hline Rondônia & 1.560 .501 & 1.142 .648 & 417.853 & 73 & 27 & 13 & 29 & -16 \\
\hline
\end{tabular}

Fonte: IBGE, 2010.

Organização: Autores.

O fenômeno migratório comparece como variável central na formação territorial de Rondônia, principalmente a partir da colonização agrícola iniciada em 1970. Contudo, dado o declínio da migração interestadual na década de 1990, esse processo mudou de escala, restringindo-se à migração intraestadual no sentido campo-campo e campo-cidade (Tabela 3). A migração intraestadual e a dinâmica dos preços das terras no espaço agrário rondoniense indicam uma correlação, vinculando ambos os processos à demanda por terra. A população da cidade aumenta sua participação na composição demográfica, com taxa média estadual de $73 \%$, cuja variação intercensitária $(2000 / 2010)$ foi de $29 \%$, ao passo que a taxa de população rural restou negativa em $-16 \%$ para o mesmo período.

Na região do agronegócio da soja esses dados são relevantes para compreendermos o impacto do agronegócio na dinâmica populacional. No cômputo geral (Tabela 3), a população cresceu $15 \%$, taxa levemente superior à média estadual (13\%), mas centralizada em Vilhena, com crescimento de $42 \%$ na cidade e $33 \%$ no campo. Para os demais municípios dessa sub-região, o impacto negativo se concretizou no espaço agrário com variação negativa de $-15 \%$, sendo que dos 7 (sete) municípios em 5 (cinco) o crescimento negativo variou de $-9 \%$ a $-33 \%$, indicando pressão territorial em terras camponesas e centralidade regional de Vilhena. Contudo, registre-se que em Vilhena a população rural cresceu $33 \%$ em função da criação de assentamentos rurais, muitos deles derivado da luta pela terra.

$\mathrm{Na}$ análise espacial, na região do agronegócio da soja se registra expressivo declínio demográfico nas taxas de crescimento da população rural, o que nos leva a supor que há aumento da concentração de terras nessa região.
A migração campo-campo se desloca para as regiões norte/noroeste de Rondônia, registrando crescimento da população rural, cujas evidências empíricas correspondem ao surgimento de vilas e povoados em áreas que até recentemente eram compostas por florestas. No espaço rural de Porto Velho, Nova Mamoré e Buritis o fenômeno das "vilas na floresta" indica o ressurgimento de frentes pioneiras, fenômeno que cresce mesmo após as institucionalizações das políticas de ordenamento do território, a exemplo do Zoneamento Socioeconômico-Ecológico de Rondônia, aprovado em 2000 (SILVA, 2016b). Os povoados de União Bandeirantes e Rio Pardo (Porto Velho), Nova Dimensão (Nova Mamoré) e Jacinópolis (Buritis) evidenciam esse processo, cuja população rural migrou da região centro-sul de Rondônia.

$\mathrm{Na}$ escala estadual apontamos duas dimensões espaciais referentes ao acesso à terra configurada pela geografia da soja e da pecuária: no centro-sul de Rondônia a região está consolidada, considerando a perspectiva de Becker (2007); no norte-noroeste e no Vale do Guaporé (fronteira com a Bolívia) esse processo está aberto, registrando áreas recentemente convertidas à agropecuária e, sobretudo, intensa extração ilegal de madeira (crime ambiental). São regiões de ressurgimento de frentes pioneiras e de intensos conflitos agrários e territoriais (SILVA, 2016b).

Oeste parænse: o encontro da Amazônia dos rios com a Amazônia das estradas

No oeste paraense, como afirmamos, nos municípios de Santarém e Belterra, na geografia da soja há o encontro da Amazônia dos rios com a Amazônia das estradas 
(VALBUENA, 2008). São espacialidades diferentes, onde se localiza o limite do avanço espacial das commodities agrícolas na Amazônia. Diferente de Rondônia, em que a soja avança em áreas de colonização recente vinculada à agropecuária, no oeste paraense se caracteriza por ser a Amazônia dos rios, das florestas e dos povos e comunidades tradicionais extrativistas (CONCEIÇÃO, 2017).

$O$ encontro conflituoso do capital globalizado se realiza nos caminhos fluviais dos ribeirinhos, modificando o sentido do lugar, dos rios e da natureza.
Nessas áreas a solidariedade orgânica é contrastada com a solidariedade organizacional do capital (SANTOS, 1996; SANTOS; SILVEIRA, 2005; SILVA, 2015), expressas nas escalas geográficas do cotidiano multitemporal e multiespacial, em que o local e o global compõem o mosaico espaço-tempo do lugar (Figura 9). Para as comunidades ribeirinhas o rio é vida social. Para o capital é tão somente um sistema de objeto que serve ao fluxo internacional da mercadoria. Na paisagem regional os conteúdos sociais e geográficos conformam o acúmulo desigual do tempo, indicando as rugosidades do espaço e sua hibridez sociotécnica (SANTOS, 1996).

\section{FIGURA 9 - RIO TAPAJÓS: BARCOS E CANOAS DOS RIBEIRINHOS E O PORTO DA CARGILL EM SANTARÉM (2014)}

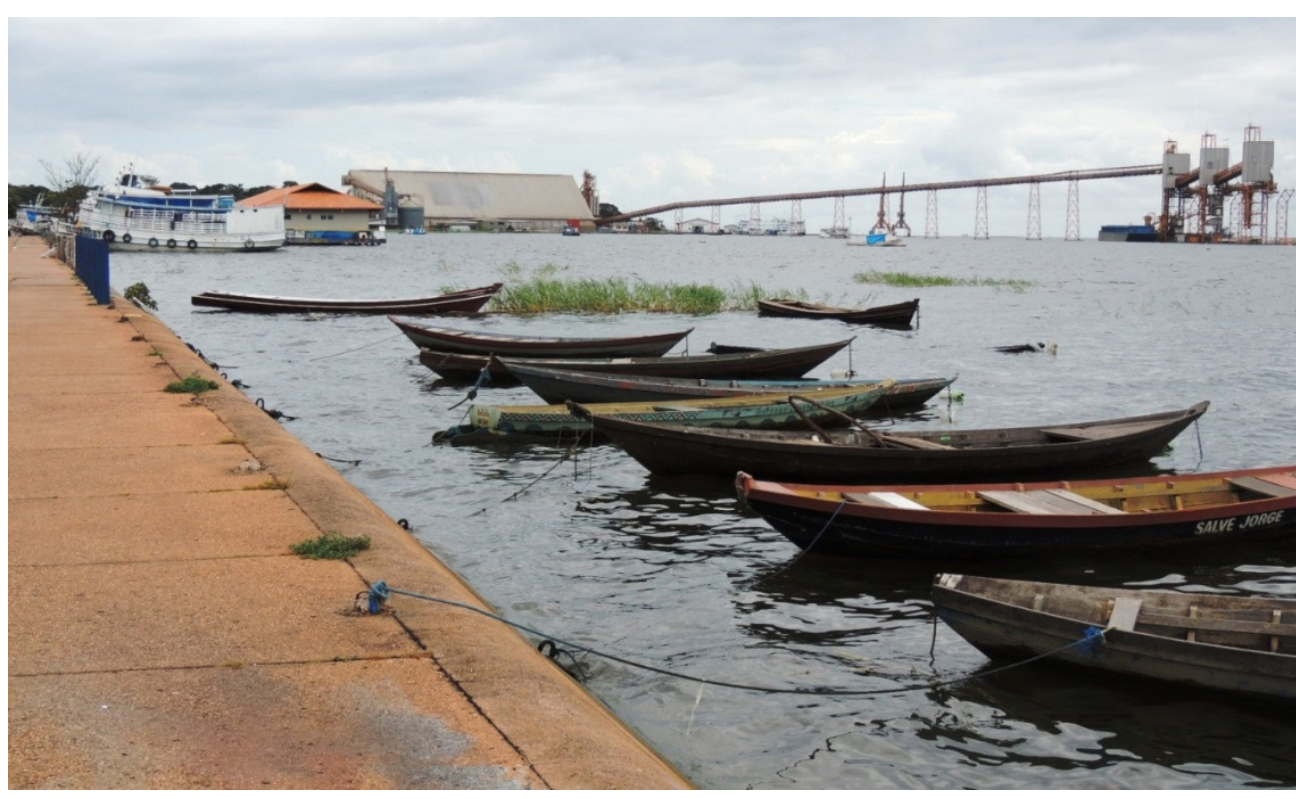

Fonte: Trabalho de Campo (2014)

Foto: R. G. C. S

Na região do Baixo Amazonas (oeste paraense), o modo de vida das comunidades rurais, ribeirinhas e urbanas se distingue pela presença dos rios nos fluxos econômicos, sociais e culturais que qualificam o espaço local e dão unidade à tríade campo-cidade-floresta como condição de entendimento do espaço total, instituindo uma geografia da diferença. Em específico, nas comunidades rurais de Santarém e Belterra, o modo de vida camponês- ribeirinho-extrativista muito se diferencia das subregiões amazônicas em que está assentada a economia da pecuária e dos grãos de soja vinculadas aos circuitos espaciais da produção (SANTOS, 1988), como ocorre no Mato Grosso e em Rondônia. Na geografia desses dois municípios o agronegócio da soja entra em cena, impondo sua racionalidade, produzindo estranhamentos nos lugares. 


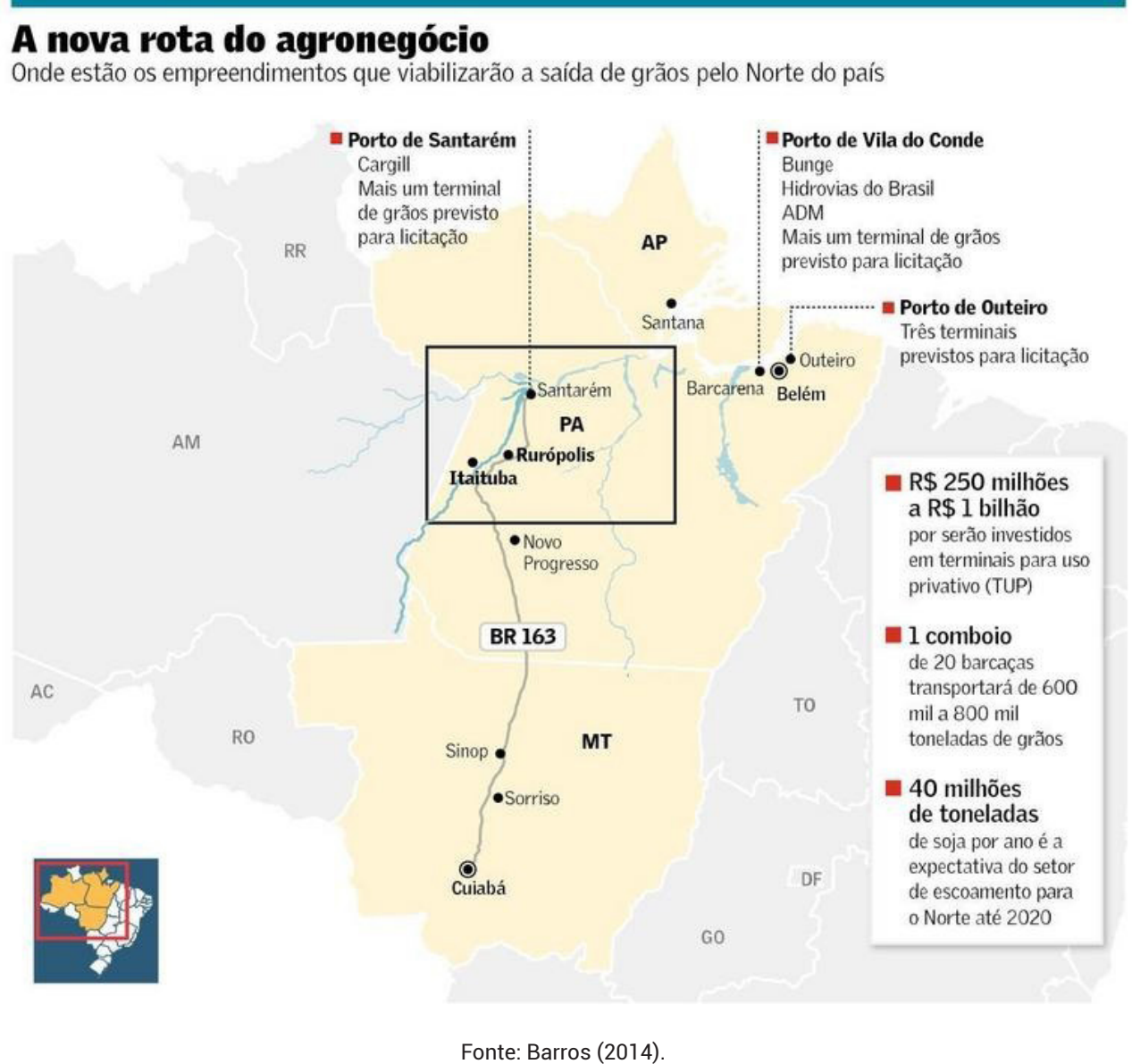

A principal pressão territorial, como argumentamos, desloca-se do Mato Grosso via eixo rodoviário da BR163. Os projetos territoriais são distintos e contraditórios, exigindo a mobilização política dos movimentos sociais à resistência e produção de contrarracionalidades ao processo de expropriação e coerção territorial imposto pelo capital globalizado (Cargill, Bunge, Amaggi, dentre outros), agentes do agronegócio (médios e grandes produtores de soja, empresas de insumos, empresas de assistência tecnológica, empresas de transportes) e poder público (governos municipal, estadual e federal).

No oeste paraense, quantidades significativas de terras destinadas ao uso camponês, onde desenvolviam uma agricultura que servia tanto à subsistência familiar quanto fornecia alimentos ao mercado local, foram convertidas em espaços da produção de commodities, causando diretamente desflorestamentos de grande magnitude e expropriação do campesinato de seus respectivos territórios. A territorialização dos agentes hegemônicos no espaço do campesinato modificou as relações de trabalho e a forma de se relacionarem e fazerem uso da natureza (CONCEIÇÃO, 2017). Todo esse processo tende a ampliar a escala geográfica das dinâmicas territoriais se confirmadas as obras de infraestruturas rodoviária, hidroviária, hidroportuária e ferroviária, que transformarão o oeste paraense em novo eixo de fluidez territorial do Brasil (ARROYO, 2001), escoando a produção agropecuária do norte e médio norte do Mato Grosso (Figura 10). Com a demanda da China por grãos e minérios, a saída pelo corredor de transporte denominado Arco Norte tende a acelerar, considerando a redução do custo de transporte em até $34 \%$, o que potencializa a produção de grãos na Amazônia, especialmente na região oeste do Pará (BARROS, 2014). Estima-se, segundo os estudos do Rabobank, banco de origem holandesa, que as exportações de soja pelos portos de Manaus (Amazonas), Santarém e Barcarena (Pará) e Itaqui (Maranhão) podem crescer até 130\% em 10 anos, considerando os investimentos anunciados pelas empresas ADM, Amaggi, Bunge, Cargill, Fiagril, Hidrovias do Brasil e Louis Dreyfus (LOPES, 2016).

As cartografias geopolíticas estão postas pelo capital hegemônico. Anuncia-se para o oeste paraense todo um conjunto de transformações espaciais ligadas aos vetores externos da globalização. A Amazônia dos rios e da floresta, dos espaços ribeirinhos e camponeses, tendem a sofrer compressões espaçotemporais aceleradas pela geopolítica mundial da soja, povoando a paisagem rural com objetos técnicos. Por conseguinte, com a pavimentação, ainda inconclusa, da rodovia BR-163 sob a iniciativa do governo federal e a ampliação portuária nas mar- 
gens do rio Tapajós, novos processos de mercantilização das terras camponeses são estimulados e pressionados por médios e grandes proprietários, empresas do agronegócio nacional e pelo capital global (TORRES, 2005). Em muitas áreas de Belterra e Santarém, as chácaras, os sítios e/ou colônias de camponeses - como são titulados pelos sujeitos sociais - foram convertidos em espaços da produção de grãos a partir da compra ou de arrendamentos de terras feitos por grandes fazendeiros.

O que outrora existia no eixo da rodovia Santarém-Cuiabá, que engloba o município de Belterra, perfaziam grandes áreas de floresta conservada e/ou preservada, utilizadas pelo campesinato para o extrativismo animal e vegetal, e no desenvolvimento de uma agricultura artesanal, familiar e de subsistência. Sem camponeses na terra, dado a expropriação e a migração para outras áreas da região, o fato se configura como um processo de "trituração" da floresta com o uso de máquinas pesadas e a preparação do solo para o cultivo de grãos. Esse espaço expressa as múltiplas contradições geradoras das conflitualidades entre camponeses e sojicultores, no encontro conflituoso da Amazônia dos rios e Amazônia das estradas.

\section{Considerações finais}

A expansão da soja na Amazônia atinge espaços territorializados pelo campesinato, que passa a sofrer pressões do capital globalizado. Se nas décadas de 1960/1990 o capital se realizava através da mineração e da energia elétrica, no campo as grandes fazendas de gado e empresas madeireiras compunham a paisagem agrária. 0 camponês se relacionava com esses sujeitos do capital, ora em conflito agrário, ora com a produção agrícola complementar comercializada nas cidades na escala local e regional.

Contemporaneamente, a reestruturação produtiva da agricultura atinge a Amazônia a partir do Mato Grosso, expandindo-se para áreas de Rondônia e do Pará e, sobremaneira, impactando a espacialidade camponesa. As verticalidades (SANTOS, 1996) do agronegócio fazem parte do cenário agrário/agrícola e regional do oeste do Pará e do sul de Rondônia, no qual esses espaços dão sentido ao funcionamento global da economia, instaurando novas lógicas da globalização (SILVA, 2015).

Em verdade, há a formação em manchas do meio técnicocientífico-informacional (SANTOS, 1996; SILVA, 2014a e 2015), onde os agentes hegemônicos vão suprimindo e dominando as comunidades camponesas, produzindo as contradições e acentuando as migrações campo-cidade ou campo-campo. Entretanto, o campesinato, enquanto modo de vida e classe social, se (re)produz no interior do modo de produção capitalista e cria estratégias de resistência ao modelo excludente e antagônico (OLIVEIRA, 1991), em que o aumento dos conflitos no campo por terra, subsolo, água e floresta são os tristes indicadores desses acirramentos socioterritoriais.

As geografias que analisamos nos municípios da Amazônia indicam que as transformações forçadas pelos fluxos da agricultura globalizada não se realizam somente em áreas de densidade técnica e produtiva, mas em regiões periféricas que acabam sendo reserva de lugares do capital global (SILVA, 2014a e 2015). O território e seus diversos modos de existência, dialeticamente, reúnem e separam os processos sociais que thes dão vida. Essas disputas territoriais contemporâneas na Amazônia cristalizam a produção do espaço agrário e regional vinculado às variáveis globais. Sua leitura passa, numa abordagem teórico-metodológica, pelo entendimento do espaço como produção social, como totalidade concreta. 
ALVES, V. E. L. (org.) (2015) Modernização e regionalização nos cerrados do Centro-Norte do Brasil. 1. ed. Rio de Janeiro: Consequência Editora.

ARROYO, M. M. (2001) Território nacional e mercado externo: uma leitura do Brasil na virada do século XX. Tese de doutorado. Departamento de Geografia, FFLCH/USP, São Paulo.

BARROS, B. (2014) Tapajós inverte fluxo de exportação de grãos. Jornal Valor, São Paulo, p. B14, 25 fev. 2014.

BECKER, B. (2007) Amazônia: geopolítica na virada do III milênio. 2. ed. Rio de Janeiro: Garamond.

BERNARDES, J. A. (2010) O novo tempo do capital no cerrado: a criação de novos territórios produtivos. In: BERNARDES, J. A., ARACRI, L. A. (orgs.). Espaço e circuitos produtivos: a cadeia carne/grãos no cerrado mato-grossense. Rio de Janeiro: Arquimedes.

BRASIL. (2015) Ministério da Agricultura, Pecuária e Abastecimento (MAPA). Projeções do Agronegócio - Brasil 2014/2015 a 2024/2025 - Projeções de Longo Prazo. Brasília, julho de 2015.

CONCEIÇÃO, F. S. (2017) A territorialização do capital e a expansão do agronegócio sojeiro: lutas e (re)existências dos camponeses/camponesas das comunidades Nova Esperança e Nova Aliança no município de Belterra-Pará. Dissertação de Mestrado em Geografia da Universidade Federal de Rondônia-UNIR. Porto Velho.

CPT-RO. (2014) Comissão Pastoral da Terra de Rondônia. Vilhena, cidade de conflitos agrários. 8 de novembro de 2013. Disponível em: <http://cptrondonia.blogspot.com.br/2013/03/vilhena-cidade-de-conflitos-agrarios.html>. Acesso em: 12 de ago de 2014.

(2016) Conflitos no campo Brasil 2016. Goiânia, CPT-Nacional.

ELIAS, D. (2012) Relações campo-cidade, reestruturação urbana e regional no Brasil. XII Coloquio de Geocrítica, Universidad Nacional de Colombia, Bogotá, 7 a 11 de maio de 2012.

FNP. (2015) Preços das terras têm forte alta nos Estados do Norte. Informa Economics FNP - Valor Econômico, 24/4/2015. Disponível em: <http://www.informaecon-fnp.com/noticia/11519>. Acesso em: 30 de abril de 2015.

IBGE. (2006). Censo Agropecuário - 2006: Brasil, grandes regiões e unidades da federação. Rio de Janeiro.

(2015) Instituto Brasileiro de Geografia e Estatística. Produção Agrícola Municipal. Rio de Janeiro.

(2010) Instituto Brasileiro de Geografia e Estatística. Censo Demográfico - 2010: Brasil, grandes regiões e unidades da federação. Rio de Janeiro.

LOPES, F. (2016) Exportação de soja pelo Norte deve crescer 130\% em 10 anos. Jornal Valor, São Paulo, 25 jun. 2016. Disponível em: <http://www2.valor.com.br/agro/4611197/exportacao-de-soja-pelo-norte-deve-crescer-130-em10-anos>. Acesso em: 15 de outubro de 2016.

MCMICHEL, P. (2016) Regimes alimentares e questões agrárias. 1. ed. São Paulo/Porto Alegre: Editora Unesp/Editora da UFRGS.

OLIVEIRA, A. (1991) A agricultura camponesa no Brasil. São Paulo: Ed. Contexto.

PORTO-GONÇALVES, C. W. (2001) Amazônia, Amazônias. São Paulo: Contexto.

RIBEIRO, A. F. A.; SILVA, R. G. C.; CORREA, S. S. (2015) Geografia da soja em Rondônia: monopolização do território, regionalização e conflitos territoriais. Campo - Território, v. 10, p. 180-201. Disponível em:<http://www.seer.ufu.br/ index.php/campoterritorio/article/viewFile/28439/17010>. Acesso em: 17 de dezembro de 2015.

SANTOS, M. (1988) Metamorfoses do espaço habitado: fundamentos teóricos metodológicos da Geografia. 1. ed. São Paulo: Hucitec.

(1996) A Natureza do Espaço: técnica e tempo, razão e emoção. São Paulo: HUCITEC.

(2005) Da totalidade ao lugar. São Paulo: Edusp.

SANTOS, M; SILVEIRA, M. L. (2005) O Brasil: território e sociedade no início do século XXI. 8. ed. Rio de Janeiro/São Paulo: Record.

SCHLESINGER, S.; NORONHA, S. (2006) O Brasil está nu! O avanço da monocultura da soja, o grão que cresceu demais. Rio de Janeiro: FASE. 
SILVA, R. G. C. (2009) Globalização e dinâmicas territoriais em Rondônia - Região Amazônica. Geograficando - Revista de Estudios Geográficos, v. 5, p.41-61.

(2012) Das margens do Madeira ao interior da floresta: percursos da formação socioespacial de Rondônia (1970-1995). In: Colonização, Território e Meio Ambiente em Rondônia: reflexões geográficas. 1. ed. Curitiba: Editora SK.

(2014a) A regionalização do agronegócio da soja em Rondônia. GEOUSP - Espaço e Tempo, São Paulo, v. 18, n. 2 , p. 298-312.

(2014b) Globalização e fragmentação do espaço agrário em Rondônia. RDE - Revista de Desenvolvimento Econômico, v. XVI, p. 163-174.

(2015) Amazônia globalizada: da fronteira agrícola ao território do agronegócio - o exemplo de Rondônia. Confins - Revoe franco-brésilienne de géographie [On-line], 23, posto on-line no dia 1 março 2015. Disponível em: <http://confins.revues.org/9949>. Acesso em: 02 de março de 2015.

(2016a) Agronegócio e campesinato em Rondônia. In: Geografia Agrária no Brasil: disputas, conflitos e alternativas territoriais. Jundiaí: Paco Editorial.

(2016b) Agentes, procesos y conflictos en la gestión territorial en el estado de Rondônia (Brasil). Polis, Santiago, v. 15, n. 45, p. 319-344, dic. 2016. Disponível em: <http://dx.doi.org/10.4067/S0718-65682016000300016>. Acesso em: 10 de março de 2017.

THÉRY, H. (1976) Rondônia - Mutations d'un Territoire fédéral en Amazonie Brésilienne. Paris, Université Paris I. (Tese de Doutorado)

(2012) Rondônia mutações de um Território federal na Amazônia federal. Curitiba: SK Editora.

TORRES, M. (org.) (2005) Amazônia revelada. Brasília: Cnpq.

TRINDADE JR., S. C. C.; SILVA, M. A. P.; AMARAL, M. D. B. (2008) Das "janelas" às "portas" para os rios: compreendendo as cidades ribeirinhas na Amazônia. In: Cidades ribeirinhas na Amazônia: mudanças e permanências. Belém: Edufpa.

VALBUENA, R. (2008) Santarém, entre la Amazonia de los ríos y la Amazonia de las carreteras. Confins - Revue franco-brésilienne de géographie [On-line], 3 | 2008, posto on-line no dia 24 abril 2008, consultado em 1 abril 2016. Disponível em: <http://confins.revues.org/3903>.

VALVERDE, O. (coord.) (1979) A Organização do Espaço na faixa da Transamazônica: introdução sudoeste amazônico e regiões vizinhas. Rio de Janeiro: IBGE/INCRA. v. 1. 